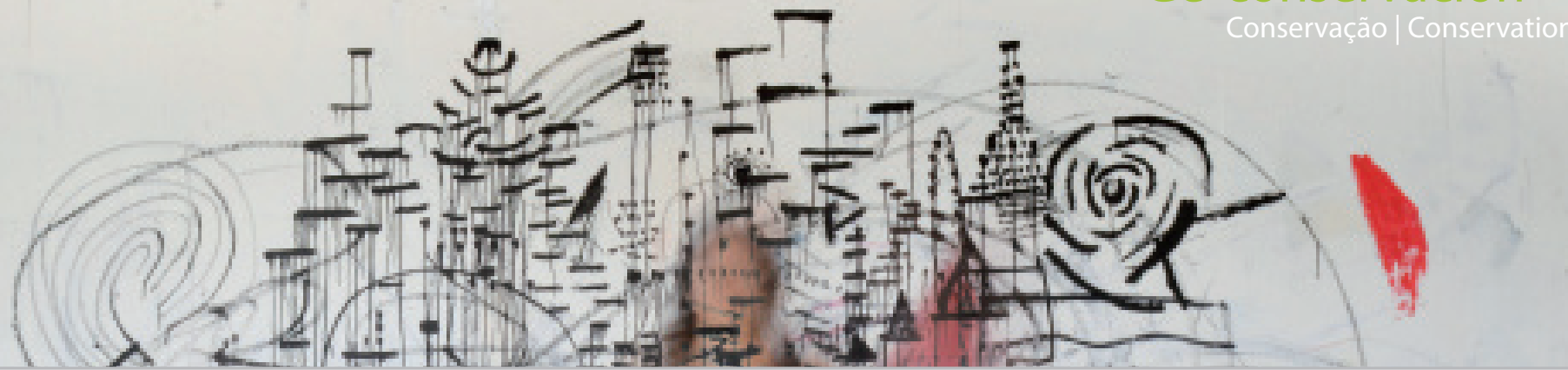

\title{
Sistemas de limpieza gelificados para pinturas acrílicas en emulsión: una revisión de la literatura científica
}

\author{
Irene Cárdaba López, Álvaro Solbes García
}

\begin{abstract}
Resumen: Las pinturas acrílicas en emulsión acuosa se han utilizado en el arte de forma masiva desde los años 60 . Sus propiedades ópticas y versatilidad posibilitaron su rápida incorporación al ámbito artístico, convirtiéndola en una de las técnicas más reconocibles a nivel internacional. Desde entonces, muchos artistas se han servido de estos productos sintéticos y sus derivados para realizar sus obras, conformando un gran acervo en fondos y colecciones que hoy en día presenta problemas de conservación. Lo más grave de esta situación es que los problemas identificados están intrínsecamente relacionados con su composición y propiedades de envejecimiento. En general, las películas acrílicas son muy sensibles a los solventes orgánicos y el agua, por lo que los métodos de limpieza tradicional no son adecuados para su intervención. Esta publicación pone en contexto parte relevante de la literatura científica referente a los nuevos métodos de limpieza basados en sistemas acuosos y gelificados.
\end{abstract}

Palabras clave: pinturas acrílicas, limpieza acuosa, geles rígidos, arte contemporáneo, conservación

\section{Gelled cleaning systems for acrylic emulsion paints: a scientific literature review}

Abstract: Acrylic emulsion paints have been widely used in art since the ' 60 s. Their good optical properties and versatility triggered their rapid incorporation into the artistic field. Thus, becoming one of the most internationally recognizable techniques. Since then, many artists have employed these synthetic products and their derivatives to do their works, forming extensive collections that nowadays show considerable conservation problems. The main concern regarding the degradation of this kind of artwork is the intrinsic relationship with their composition and ageing properties. In general, acrylic films are very sensitive to organic solvents and water, so traditional cleaning methods are unsuitable for their intervention. This paper puts a relevant part of the scientific literature concerning new cleaning methods based on aqueous and gelled systems.

Keywords: acrylic paints, water based cleaning, rigid gels, contemporary art, conservation

\section{Introducción}

Desde su creación a mediados de los años 50, las pinturas acrílicas en emulsión acuosa han sido ampliamente utilizadas en el ámbito artístico como alternativa a la pintura al óleo. Sin embargo, los especialistas en conservación y restauración observaron que, tras cortos períodos de exposición al ambiente, las obras acumulaban suciedad superficial por diversos motivos asociados a su composición (Jablonski et al. 2003). Este fenómeno de envejecimiento acelerado ha supuesto un grave problema para la conservación, pues la aplicación de cualquier método de limpieza se ve condicionado por la delicada morfología de la película acrílica y su alta sensibilidad a los solventes orgánicos o el agua. En este sentido, la literatura ha reportado ampliamente (Ormsby y Learner 2009) que los problemas más relevantes están

\section{Introduction}

Since their creation in the mid-1950s, acrylic emulsion paints have been widely used in the artistic field as an alternative to oil paint. However, after a short period of exposure to the environment, conservation specialists observed that the artworks accumulated surface dirt for different reasons associated with their composition (Jablonski et al. 2003). This phenomenon of accelerated ageing has been a severe problem for conservation since the application of any cleaning method is conditioned by the acrylic film's delicate morphology and its high sensitivity to organic solvents or water. In this sense, the literature has widely reported (Ormsby and Learner 2009) that the most relevant problems are associated with the presence of certain hydrophilic additives such 
asociados con la presencia de ciertos aditivos hidrófilos como agentes humectantes y dispersantes (Whitmore, Colaluca y Farrell 1996; Agarwal y Farris 1999; Ploeger et al. 2004).

Las pinturas en emulsión acrílica son fluidos complejos formados a partir de un aglutinante (la resina acrílica o látex), pigmentos y multitud de aditivos que favorecen su estabilidad en el medio acuoso (Croll 2007). Los aditivos son fundamentales para que la pintura pueda conservarse en óptimas condiciones y tenga determinadas propiedades de uso, reología o proceso de curado (Ormsby y Learner 2014). Tanto humectantes como dispersantes se introducen en cantidades considerables en dos momentos de la formulación. Por un lado, durante el proceso de polimerización de la resina y por otro, para aglutinar cargas y pigmentos en la fase acuosa (De Sousa Ramos Félix Silva 2011). Debido a su naturaleza hidrófoba, los humectantes permiten emulsionar las partículas sólidas de polímeros y pigmentos en agua, mientras que los dispersantes evitan que estas partículas floculen o formen agregados, manteniendo una dispersión homogénea de la emulsión (Belaroui et al. 2003). Al igual que otros componentes ambos aditivos permanecen en la película pictórica seca conservando su inherente sensibilidad al agua.

Como agentes humectantes, la industria suele utilizar una combinación de tensoactivos iónicos y no iónicos (Hoogland y Boon 2009), siendo los tensoactivos no iónicos del tipo polietilenglicol (PEG) los más problemáticos para la conservación, ya que pueden afectar significativamente las propiedades ópticas y mecánicas de la película pictórica (Wolbers, Norbutus y Lagalante 2012). Se considera que los tensoactivos tienen una alta movilidad y pueden migrar desde el interior de la película acrílica a la superficie por diferentes mecanismos asociados con la temperatura de transición vítrea ( $\mathrm{Tg}$ ), el tipo de copolímero o el proceso de curado entre otros fenómenos fisicoquímicos (Digney-Peer et al. 2004). Este aditivo se puede agrupar en zonas localizadas o de manera continua modificando la saturación y el brillo de la pintura y al mismo tiempo, atrapando la suciedad ambiental (Mallégol et al. 2002). Durante el proceso de secado y formación de la película, los tensoactivos se acumulan principalmente cerca de la superficie, cerca del soporte o al interior de la matriz polimérica pudiendo formar agregados hidrófilos con alta capacidad de absorción por capilaridad (Aramendia et al. 2003). Estos tensoactivos añadidos como estabilizadores de la resina pueden suponer entre el 2 y $6 \%$ del peso total de la película seca (Learner 2004).

De manera similar, los dispersantes permanecen en la película conservando todas sus propiedades y capacidad hidrófila. Las pinturas acrílicas utilizan polímeros de alto peso molecular como los ácidos poliacrílicos (PAA) para ejercer esta función (Stavroudis y Doherty 2013). Estas macromoléculas presentan una estructura amorfa helicoidal que tiene la capacidad de aumentar hasta 1000 veces su tamaño y absorber agua en función del pH de una solución. Aunque los PAA mantienen un bajo estado de hidratación con la acidez, al exponerlos a un ambiente alcalino se ionizan rápidamente pasando a un estado expandido y sensible a la absorción (Dillon, Lagalante y as wetting and dispersing agents (Whitmore, Colaluca and Farrell 1996; Agarwal and Farris 1999; Ploeger et al. 2004).

Acrylic emulsion paints are complex fluids formed from a binder (acrylic resin or latex), pigments, and many additives that favour their stability in the aqueous medium (Croll 2007). Additives are essential for the paint to be preserved in optimal conditions and to have specific properties of use, rheology or curing process (Ormsby and Learner 2014). Both wetting agents and dispersants are introduced in considerable quantities at two points in the formulation. On the one hand, during the resin polymerization process and on the other, to blend fillers and pigments in the aqueous phase (De Sousa Ramos Félix Silva 2011). Due to their hydrophobic nature, wetting agents allow emulsifying solid particles of polymers and pigments in water. At the same time, dispersants prevent these particles from flocculating or forming aggregates, maintaining a homogeneous dispersion of the emulsion (Belaroui et al. 2003). Like other components, both additives remain in the dried film, retaining their inherent sensitivity to water.

As wetting agents, the industry usually uses a combination of ionic and non-ionic surfactants (Hoogland and Boon 2009). Within the non-ionic surfactants, the polyethene glycol (PEG) type is considered the most problematic for preservation, and they can significantly affect the film's optical and mechanical properties (Wolbers, Norbutus and Lagalante 2012). Surfactants have high mobility and can migrate from inside the acrylic film to the surface by different mechanisms associated with the glass transition temperature ( $\mathrm{Tg})$, the type of copolymer or the curing process, among other physicochemical phenomena (Digney-Peer et al. 2004). This additive can be grouped in localized zones or a continuous manner, modifying the saturation and gloss of the paint and, at the same time, trapping environmental dirt (Mallégol et al. 2002). During the drying and film formation process, surfactants accumulate mainly near the surface, close to the support or inside the polymeric matrix and can form hydrophilic aggregates with high absorption capacity by capillarity (Aramendia et al. 2003). These surfactants added as resin stabilizers can account for 2 to $6 \%$ of the dry film total weight (Learner 2004).

Similarly, dispersants remain in the film while retaining all their properties and hydrophilic capacity. Acrylic paints use high molecular weight polymers such as polyacrylic acids (PAA) to perform this function (Stavroudis and Doherty 2013). These macromolecules exhibit an amorphous helical structure that can increase up to 1000 -fold and absorb water as a function of the $\mathrm{pH}$ solution. Although PAAs maintain a low hydration state with acidity, they rapidly ionize when exposed to an alkaline environment, transitioning to an expanded and absorption-sensitive state (Dillon, Lagalante and Wolbers 
Wolbers 2014). Las pinturas acrílicas suelen estar tamponadas a un $\mathrm{pH}$ de entre 9 y 10 , favoreciendo así el hinchamiento de los PAA y otorgando a la pintura una textura cremosa y reología adecuada para uso (Learner 2004). A nivel fisicoquímico, la adición de una solución alcalina en el sistema desplaza los hidrógenos de los grupos carboxílicos $(-\mathrm{COOH})$ para transformarlos en grupos carboxilatos (-COO) que se repelen entre sí (Hogfeldt et al. 1989). La repulsión electrostática de estos grupos es la que produce la elongación de la cadena de PAA en la matriz, aumentando considerablemente el volumen de la película acrílica seca y modificando sus propiedades mecánicas de forma irreversible.

\section{Pinturas acrílicas y sus propiedades}

\section{—Hinchamiento y extracción de materiales}

Con relación a la conservación de las pinturas acrílicas, la literatura considera destacar los fenómenos de hinchamiento por absorción de agua (Snuparek et al. 1983; Agarwal y Farris 1999; Owen, Ploeger y Murray 2004) y la posterior extracción de materiales constitutivos (Whitmore y Colaluca, 1995; Ploeger et al. 2004; Zumbühl et al. 2007), como los efectos más negativos para su pervivencia en el tiempo. Ambas circunstancias se pueden dar de forma natural, por la absorción de la humedad ambiente; de forma accidental, por la acción de cualquier agente de deterioro externo; o debido a diferentes procesos de restauración, especialmente los de limpieza química.

El hinchamiento porabsorción de la película acrílica se produce por capilaridad desde el primer minuto de contacto (Ormsby et al. 2007), por ejemplo, con un solvente orgánico o cualquier otro tipo de solución acuosa. La capacidad de absorción depende, como se ha señalado, de los diferentes materiales hidrosolubles presentes (tensoactivos y dispersantes), pero también de su cantidad, de la elasticidad del polímero, del tamaño de partícula de la resina y los procesos de curado y envejecimiento (Butler, Fellows y Gilbert 2003; Whitmore, Morris y Colaluca 2007). La absorción se produce hasta la saturación entre los 5 y 10 minutos siguientes al contacto y puede estar influenciada por una adecuada coalescencia de la película o por la degradación de los materiales hidrosolubles. Ploeger et al. (2007) observó que este fenómeno era diferente entre películas pigmentadas y no pigmentadas, señalando que pigmentos y otros aditivos pueden afectar al proceso. En este sentido, son destacables por su capacidad hidrófila ciertos compuestos como espesantes y pigmentos del tipo aluminosilicatos (Ploeger et al. 2005).

Otros autores como Whitmore, Morris y Colaluca (2007), señalan que la absorción y la difusión de una solución se reduce entre un $25-50 \%$ para película ya tratadas, las cuales han reducido sensiblemente sus materiales hidrosolubles, extraídos por desorción. De la misma manera, se considera que las pinturas con pigmentos orgánicos tienden a absorber e hinchar en mayor medida que las que contienen inorgánicos [Figura 1], posiblemente por una mayor presencia de aditivos hidrófilos en su composición (Digney-
2014). Acrylic paints are usually buffered to a pH between 9 and 10, thus favouring the swelling of PAAs and giving the paint a creamy texture and rheology suitable for use (Learner, 2004). From a physicochemical point of view, the addition of an alkaline solution to the system displaces the hydrogen atoms of the carboxylic groups $(-\mathrm{COOH})$, transforming them into carboxylate groups (-COO-) repelling each other (Hogfeldt et al. 1989). The electrostatic repulsion of these groups produces the elongation of the PAA chain in the matrix, considerably increasing the volume of the dry film and modifying its mechanical properties irreversibly.

\section{Acrylic paints properties}

\section{—Swelling and materials extraction}

Concerning the conservation of acrylic paints, the literature considers the phenomena of swelling due to water absorption (Snuparek et al. 1983; Agarwal and Farris 1999; Owen, Ploeger and Murray 2004) and the subsequent extraction of constituent materials (Whitmore and Colaluca, 1995; Ploeger et al. 2004; Zumbühl et al. 2007), as the most damaging effects on their survival over time. Both can occur naturally, by absorbing ambient humidity, accidentally, by any external deterioration agent, or due to different restoration processes, especially chemical cleaning.

Acrylic film swelling by absorption occurs by capillarity from the first minute of contact (Ormsby et al., 2007), for example, with an organic solvent or any other type of aqueous solution. The absorption capacity depends, as noted, on the different water-soluble materials present (surfactants and dispersants), but also their quantity, the elasticity of the polymer, the particle size of the resin and the curing and ageing processes (Butler, Fellows and Gilbert 2003; Whitmore, Morris and Colaluca 2007). Absorption occurs to saturation within 5 to 10 minutes after contact and may be influenced by good coalescence film or water-soluble material degradation. Ploeger et al. (2007) observed that this phenomenon differed between pigmented and unpigmented films, noting that pigments and other additives can affect the process. In this sense, certain compounds such as thickeners and aluminosilicate type pigments are noteworthy for their hydrophilic capacity (Ploeger et al. 2005).

Other authors such as Whitmore, Morris and Colaluca (2007) point out that solution absorption and diffusion is reduced by $25-50 \%$ for already treated films, which have significantly reduced their water-soluble materials extracted by desorption. It is considered that paints with organic pigments tend to absorb and swell to a greater extent than those containing inorganics [Figure 1], possibly due to a more significant presence of hydrophilic additives in their composition (Digney-Peer 
Peer et al. 2004). En cualquier caso, hay cierta convención en afirmar que, a mayor absorción de una solución, mayor es el fenómeno de hinchamiento y extracción de materiales. et al. 2004). In general, a convention says that the greater the absorption of a solution, the greater the swelling and extraction of materials.

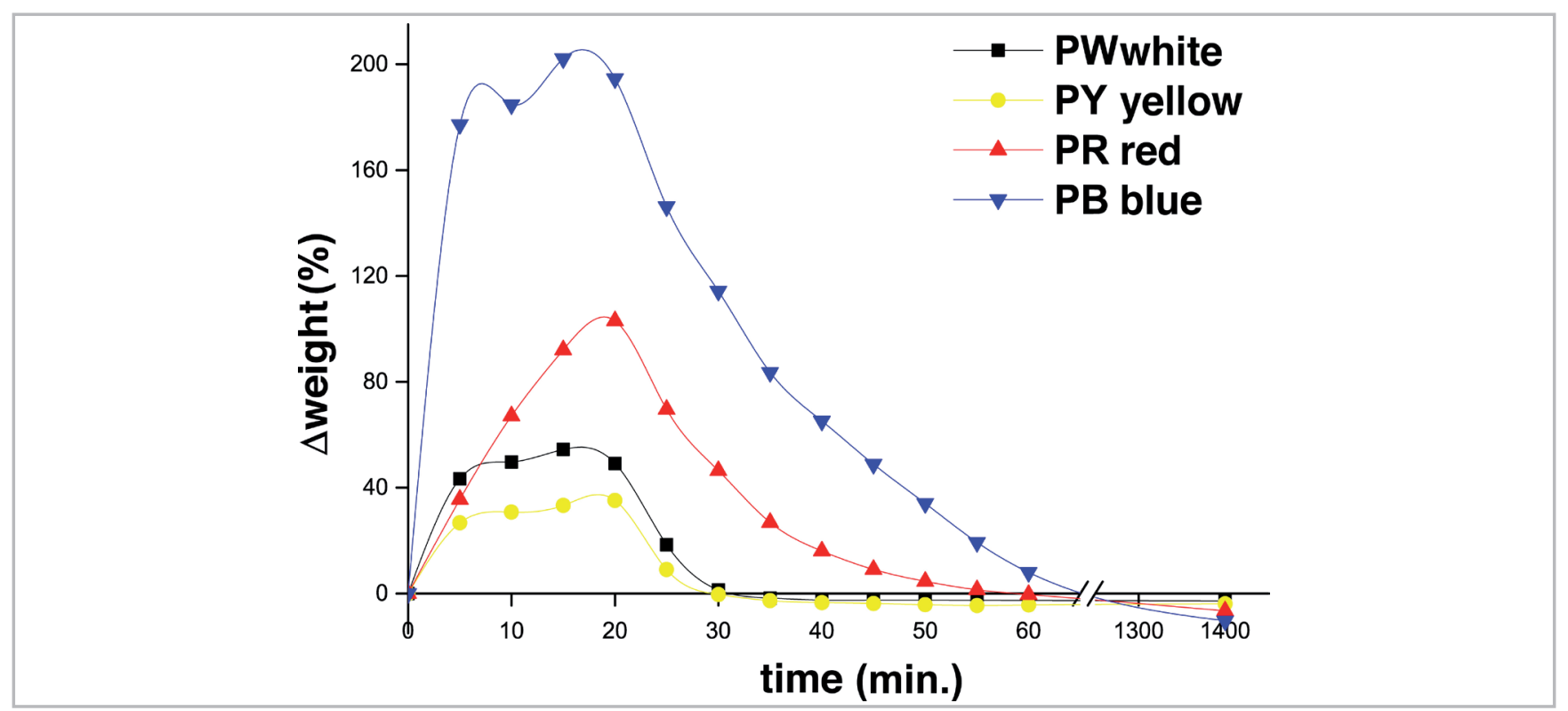

Figura/Figure 1- Pruebas de laboratorio realizadas por los autores a partir de ensayos de absorción-desorción de cuatro películas acrílicas en agua desionizada. Destaca un incremento de peso del 200\% para una pintura azul con pigmento orgánico de dioxacina (2017). / Laboratory tests performed by the authors were based on absorption-desorption tests of four acrylic films in deionized water. A $200 \%$ weight increase for a blue paint with dioxazine organic pigment stands out (2017).

En cuanto a la extracción de materiales podemos identificar dos problemáticas destacables. Por un lado, los tensoactivos se exudan de forma natural a la superficie y, por otro lado, los fenómenos de absorción-desorción producen la pérdida de compuestos fundamentales o su reubicación en la matriz polimérica (Mallégol et al. 2002; Scalarone y Chiantore 2004). El exudado o lixiviación de los tensoactivos se produce, por ejemplo, con los cambios de temperatura y humedad relativa según la Tg del copolímero (Hayes, Golden y Smith 2007; Smith 2007). Una temperatura por debajo de la Tg generará una película mucho más rígida y comprimida en volumen, empujando a los tensoactivos fuera de la matriz. Al contrario, una temperatura más elevada producirá el efecto inverso, una película más blanda y mordiente con una matriz relajada que absorberá hacia el interior estos compuestos. Algo similar ocurre con la humedad relativa, pues las condiciones ambientales de humedad relativa alta (por encima del 40\%) implicará una mayor absorción de tensoactivos hacia el interior de la pintura y, una humedad más baja, una mayor presencia en superficie (Ziraldo et al 2015). Las primeras formulaciones para pinturas acrílicas en emulsión estaban preparadas a partir del poli etil acrilato/ metil metacrilato [p(EA/MMA)], un copolímero más rígido que su predecesor el polinbutil acrilato/metil metacrilato [p(nBA/MMA)] (Smithen 2007). El primero se caracteriza por su dureza e hidrofobicidad, por lo que la formulación está comprometida a una alta presencia de agentes humectantes y dispersantes La aparición del nuevo copolímero responde, por tanto, a la necesidad de generar un homopolímero menos rígido, con la idea de reducir estos aditivos durante
Regarding the extraction of materials, two main aspects should be considered the natural exudation of surfactants from the surface and the adsorptiondesorption phenomena result in the loss of critical compounds or their relocation in the polymer matrix (Mallégol et al. 2002; Scalarone and Chiantore 2004). Surfactant's exudation or leaching occurs, for example, with changes in temperature and relative humidity depending on the copolymer Tg (Hayes, Golden and Smith 2007; Smith 2007). A temperature below Tg will generate a much stiffer and more volume-compressed film, pushing surfactants out of the matrix. On the contrary, a higher temperature will produce the opposite effect, a softer and more morbid film with a simple matrix that will absorb these compounds into the matrix. Something similar occurs with the relative humidity since high humidity environmental conditions (above $40 \% \mathrm{RH}$ ) will imply a more excellent absorption of surfactants into the paint, and lower humidity, a more significant presence on the surface (Ziraldo et al. 2015). The first acrylic emulsion paints formulations were based on poly ethyl acrylate/methyl methacrylate [p(EA/MMA)], a stiffer copolymer than its predecessor, the poly butyl acrylate/methyl methacrylate [p(nBA/MMA)] (Smithen, 2007). Its hardness and hydrophobicity characterize the former, so the formulation is committed to a high presence of wetting and dispersing agents. Therefore, the appearance of the new copolymer responds to the need to generate a less rigid homopolymer, with the idea of reducing these additives during manufacturing 
la fabricación y asegurar una mejor absorción de los tensoactivos en la película (Ormsby et al. 2009).

Finalmente, y como se ha señalado, la extracción de componentes puede darse con la desorción de agua u otro tipo de solución. En este proceso pueden extraerse o reubicarse en la matriz polimérica, pigmentos, cargas, espesantes u otros aditivos (Ploeger et al. 2004), afectando notablemente tanto las propiedades ópticas como mecánicas de la pintura. A nivel óptico podemos hablar de cambios en la estructura superficial que modifican la saturación y el brillo original, la formación de halos blanquecinos por acumulación de tensoactivos en superficie o el embebido de la suciedad ambiental (Belaroui et al. 2003; Hoogland y Boon, 2009). A nivel mecánico, es frecuente la pérdida de adhesión y elasticidad, además de la aparición de micro perforaciones [Figura 2]. Los tensoactivos, por ejemplo, son compuestos que favorecen la plasticidad de la película y su extracción puede generar rigidez, dejando una película más quebradiza por la presencia de pequeños huecos, futuros puntos de rotura sensibles a la elongación (Hagan et al. 2007). and ensuring better surfactant absorption in the film (Ormsby et al. 2009).

Finally, and as mentioned above, components can be extracted by water desorption or other solution types. In this process, pigments, fillers, thickeners, or other additives can be removed or relocated in the polymer matrix (Ploeger et al. 2004), significantly affecting optical and mechanical paint properties. At the visual level, we can speak of surface structure changes that modify the original saturation and gloss, the formation of haziness due to the accumulation of surfactants on the surface or the environmental dirt embedding (Belaroui et al. 2003; Hoogland and Boon 2009). At the mechanical level, loss of adhesion and elasticity is frequent, in addition to the micropores appearance [Figure 2]. Surfactants, for example, are compounds that favour film plasticity. Their removal can generate rigidity, leaving a more brittle film due to the presence of small voids and future breakpoints sensitive to elongation (Hagan et al. 2007).

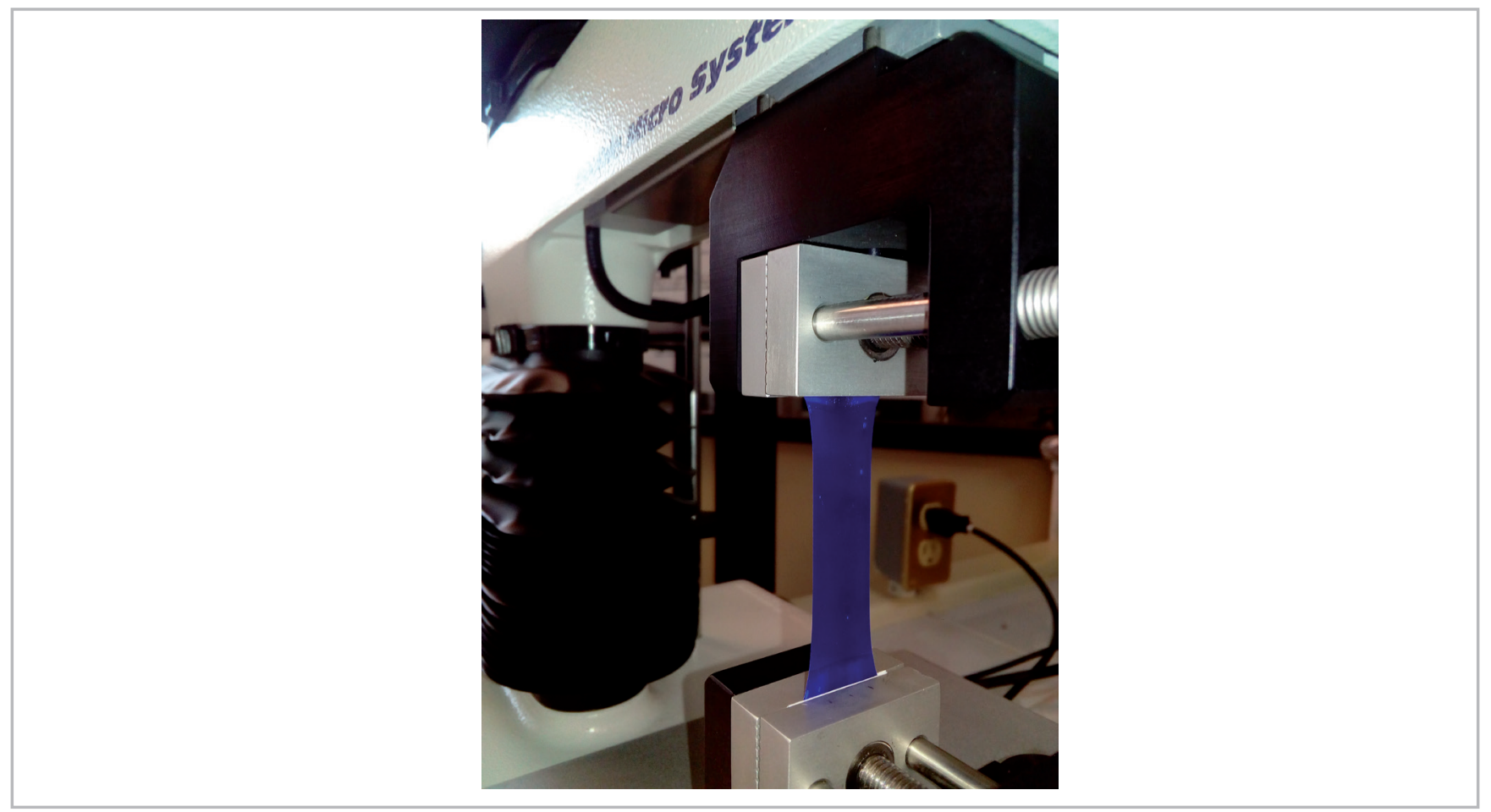

Figura/Figure 2- La rotura de una muestra de pintura acrílica azul se produce por la aparición de diminutas perforaciones asociadas a la pérdida de materiales hidrosolubles (Hagan et al. 2007). Fotografía de los autores en ensayos de laboratorio (2017). / The breakage of a blue acrylic paint sample is caused by the appearance of minute perforations associated with the loss of water-soluble materials (Hagan et al. 2007). Photograph of the authors in laboratory tests (2017).

\section{- Propiedades mecánicas de la película}

Tanto las pinturas acrílicas como otros recubrimientos elaborados a partir de esta resina sintética son considerados materiales viscoelásticos (Wicks et al. 2007). Una de las principales diferencias entre las propiedades mecánicas de un material sólido y uno viscoelástico, es que los sólidos presentan una curva de esfuerzo-deformación en la que la zona elástica y plástica son fácilmente diferenciables. En el caso de las películas acrílicas, material viscoelástico no lineal, la elasticidad

\section{- Mechanical properties}

Both acrylic paints and other coatings made from this synthetic resin are considered viscoelastic materials (Wicks et al. 2007). One of the main differences between the mechanical properties of a solid and a viscoelastic material is that solids present a stress-strain curve in which the elastic and plastic zones are easily differentiated. In acrylic films, a non-linear viscoelastic material, the elasticity varies according to the applied 
varía según el esfuerzo aplicado. Aunque se considera que con el tiempo estos materiales recuperan su tamaño una vez que ha cesado el esfuerzo, las propiedades viscoelásticas quedan afectadas irreversiblemente (Wicks et al. 2007).

Las propiedades mecánicas de los materiales viscoelásticos en un ensayo de tensión son dependientes tanto de la temperatura como de la velocidad en la que se aplica la carga, y en el caso de las pinturas acrílicas, también dependientes de otros factores como la temperatura de transición vítrea $\left(T_{g}\right)$ o el volumen de concentración de cargas y pigmentos (pigment volume concentration o PVC) (Hagan et al. 2011). Si se realiza un ensayo con una velocidad muy alta, la muestra se comportará con mucha fragilidad y poca resistencia a la rotura, mientras que a bajas velocidades presentará una adecuada plasticidad y elevados valores de deformación (Mecklenburg y Tumosa 1991). En pinturas acrílicas se han reportado efectos similares en función de la $\mathrm{T}_{\mathrm{g}}$ y los cambios de temperatura y humedad relativa: las pinturas aumentan su rigidez conforme baja la temperatura, produciéndose cierta reducción de su capacidad de deformación. Cuando la temperatura se reduce por debajo de la $\mathrm{T}_{\mathrm{g}^{\prime}}$ la película presenta un deterioro significativo de las propiedades mecánicas (menor estiramiento e incremento de la rigidez), mostrándose como un material frágil y quebradizo (Hagan et al. 2015). En cuanto a la concentración de pigmentos, se considera que un volumen alto de partículas sólidas en una pintura puede producir películas poco cohesionadas, con poca resistencia y alargamiento hasta la rotura. Esto se produce por la dificultad que muestra la resina a la hora de englobar las cargas y formar una matriz polimérica continua (Hayes, Golden y Smith 2007).

En resumen, diferentes estudios coinciden en afirmar que los tratamientos acuosos, especialmente los que implican más tiempo de contacto, modifican en gran medida las propiedades mecánicas de la película (Scalarone y Chiantore 2004; Ormsby et al. 2007). Por lo tanto, a la hora de diseñar tratamientos de restauración de tipo acuoso, se deben tener en cuenta algunas consideraciones como el pH de la solución, la conductividad, o el uso de sales neutras, ácidos orgánicos y espesantes.

\section{Los sistemas y métodos de limpieza de obras pictóri- cas}

La limpieza de las obras pictóricas es un tratamiento clave en la conservación de obras de arte. Este campo está en continuo estudio, debido a su complejidad y su carácter determinante para garantizar un correcto tratamiento. Hasta el momento, distintos profesionales han llevado a cabo estudios para evaluar los pros y los contras de cada método y sistema de limpieza de acuerdo a las características de las obras sobre las que se aplican. Es indispensable tener en cuenta los riesgos que implica cualquier intervención de limpieza sobre una superficie. Entre ellos los tres riesgos principales son: la irreversibilidad de degradación provocada por la limpieza, el riesgo para la salud implícito por el empleo de substancias tóxicas y el potencial riesgo para el medio ambiente. stress. Although it is considered that these materials will recover their size once the stress has ceased, the viscoelastic properties are irreversibly affected (Wicks et al. 2007).

During tension testing, viscoelastic materials' mechanical properties depend on both the temperature and the speed at which the load is applied. But, in the case of acrylic paints, this will rely on other factors such as the glass transition temperature $\left(\mathrm{T}_{\mathrm{g}}\right)$ or the volume concentration of fillers and pigments (pigment volume concentration or PVC) (Hagan et al. 2011). If a test is carried out at a very high speed, the sample will behave with high brittleness and low resistance to breakage, while at low rates, it will present good plasticity and high deformation values (Mecklenburg and Tumosa 1991). Similar effects have been reported in acrylic paints as a function of $\mathrm{T}_{g}$ and changes in temperature and relative humidity: the paints increase their stiffness as the temperature decreases, producing an inevitable reduction in their deformation capacity. When the temperature is reduced below $T_{g}$ the film significantly deteriorates mechanical properties (lower stretching and increased stiffness), showing itself as a brittle and fragile material (Hagan et al. 2015). Regarding pigment concentration, it is considered that a high volume of solid particles in a paint can produce poorly cohesive films, with low strength and elongation to breakage. This is caused by the difficulty shown by the resin in encompassing the fillers and forming a continuous polymer matrix (Hayes, Golden and Smith 2007).

In brief, different studies agree that aqueous treatments, especially those involving more contact time, significantly modify the film mechanical properties (Scalarone and Chiantore 2004; Ormsby et al. 2007). Therefore, when designing aqueous-type restoration treatments, considerations such as the solution $\mathrm{pH}$, conductivity, or the use of neutral salts, organic acids and thickeners must be considered.

\section{Cleaning systems and methods for the cleaning of pictorial artworks}

The cleaning of pictorial works is a necessary treatment in the conservation of works of art. This field is under continuous study due to its complexity and decisive nature to guarantee a correct treatment. So far, different professionals have carried out studies to evaluate the pros and cons of each cleaning method and system according to the characteristics of the works on which they are applied. It is essential to consider the risks involved in any cleaning intervention on a surface. Among them, the three main risks are: the irreversible degradations caused by the cleaning treatment, and the health risk implied using toxic substances and the potential risk to the environment. 
A la hora de seleccionar el tratamiento de limpieza se deben considerar tanto el agente o sistema de limpieza como el método de aplicación, pues ambos son determinantes para lograr los resultados deseados. Hasta el momento los sistemas de limpieza más comunes empleados para la limpieza de obras pictóricas se han basado sobre todo en disolventes y soluciones acuosas. Cómo método de aplicación, el más común empleado hasta la actualidad ha sido el hisopo, aplicando las soluciones de limpiezas en "libre" (Riedo 2017). Sin embargo, a partir de la incorporación de los sistemas gelificados propuestos por Richard Wolbers en los años 80 , se abrió un campo que aún hoy se mantiene en continuo desarrollo: los geles y sistemas gelificados (Riedo 2017). Esta nueva aportación surge de la necesidad de controlar mejor la acción y la liberación de los sistemas de limpieza sobre las superficies, con el fin de solventar los problemas provocados por los tratamientos de limpieza sobre las obras.

La limpieza superficial de las obras pictóricas antiguas a menudo se dirige de manera diferente, gracias a la existencia, generalmente, de una capa de protección o barniz.Sinembargo, con la llegada del arte contemporáneo y la incorporación de nuevas técnicas pictóricas, la mera eliminación del polvo depositado sobre ciertas superficies supone un desafío difícil de solventar. En muchas obras contemporáneas, la ausencia de capas de protección y barnices que protejan la obra, implica la necesidad de aplicar las limpiezas directamente sobre la pintura que, generalmente, es sensible a los agentes de limpieza. Las pinturas de emulsión acrílica concretamente, son altamente sensibles al agua y a los disolventes orgánicos polares, que provocan la hinchazón de la capa de pintura (Cárdaba 2020). Además, la interacción de los disolventes con el film acrílico puede causar la ruptura de su microestructura provocando cambios ópticos y disminuyendo su resistencia mecánica. Por otro lado, también pueden solubilizar los aditivos presentes en el interior de la capa pictórica, provocando su migración a la superficie y modificando las propiedades físico-químicas y mecánicas del film (Cárdaba 2020).

\section{Sistemas de limpieza acuosos aplicados a pinturas de emulsión acrílica. Algunas consideraciones}

La sensibilidad de los acrílicos se puede categorizar en tres propiedades principalmente: el efecto del $\mathrm{pH}$, el efecto de la fuerza iónica y el efecto en la migración de surfactantes, ya que afectan a su estructura física interna (Stavroudis 2013).

Los acrílicos son materiales ligeramente alcalinos, formulados en pH 9.5 (Stavroudis 2013). Aunque la pintura al secar es insoluble en agua, esta sigue manteniendo la capacidad de hidratarse, hincharsey ablandarse en presencia de soluciones alcalinas. Esto provoca la alteración de la capa pictórica, favorece la lixiviación de materiales de la pintura y propicia la incrustación de la suciedad. Sin embargo, en soluciones suficientemente ácidas, estas alteraciones de la pintura se minimizan al máximo (Stavroudis 2013).

La conductividad es otro de los parámetros que deben ser controlados a la hora de preparar una disolución de
When selecting the cleaning treatment, the cleaning agent or system and the application method must be considered since both are decisive to achieving the desired results. So far, the most common cleaning systems used to clean pictorial works have been based mainly on solvents and aqueous solutions. As an application method, the most commonly used to date has been the cotton swab, releasing the cleaning solutions in "free" (Riedo 2017). However, from the incorporation of gelled systems proposed by Richard Wolbers in the 80 s, a field was opened that even today remains in continuous development: gels and gelled systems (Riedo 2017). This new contribution arises from the need to better control the action and release of cleaning systems on surfaces, to solve the problems caused by the cleaning treatments on the works.

The surface cleaning of ancient pictorial works is often directed differently, thanks to the existence, generally, of a protective layer of varnish. However, with the arrival of contemporary art and the incorporation of new pictorial techniques, the mere removal of dust deposits on certain surfaces is challenging to solve. In many contemporary works, the absence of layers of protection and varnishes that protect the work implies the need to apply the cleanings directly on the paint that, generally, is sensitive to the cleaning agents. Specifically, acrylic emulsion paints are highly sensitive to water and polar organic solvents, which cause swelling of the paint layer (Cárdaba 2020). In addition, the interaction of solvents with the acrylic film can cause the rupture of its microstructure, causing optical changes and decreasing its mechanical strength. On the other hand, solubilization of additives can occur inside the pictorial layer, promoting additive migration to the surface. This results in a modification of the physicochemical and mechanical properties of the film (Cárdaba 2020).

\section{Aqueous cleaning systems applied to acrylic emulsion paints. Some considerations}

The sensitivity of acrylics can be categorized based on three main properties: the effect of $\mathrm{pH}$, ionic strength and the impact on the migration of surfactants since they affect their internal physical structure (Stavroudis 2013).

Acrylics are slightly alkaline materials, formulated at $\mathrm{pH}$ 9.5 (Stavroudis 2013). Although the paint, when drying, is insoluble in water, it still maintains the ability to hydrate, swell and soften in the presence of alkaline solutions. This causes the alteration of the pictorial layer, favours the leaching of materials from the painting and promotes the inlay of dirt. However, insufficiently acidic solutions, these paint alterations are minimized to the maximum (Stavroudis 2013).

Conductivity is another parameter that must be controlled when preparing a cleaning solution. It 
limpieza. Esta mide tanto la concentración de iones en la solución, como su movilidad dentro de la misma (Doherty 2012). La película formada por una pintura acrílica actúa como una membrana semipermeable. A través de los microporos de la superficie, se puede producir el intercambio de materiales entre la solución de limpieza y la pintura, a causa de lo que se denomina la fuerza osmótica. Este movimiento de materiales ocurre cuando la concentración relativa de sales solubles de ambas partes, tienden a equilibrarse porque son diferentes. Por tanto, es necesario formular soluciones de limpieza isotónicas, es decir, con valores de fuerza iónica similares a los de la pintura, para que este intercambio de iones no ocurra (Stavroudis 2013). De acuerdo con las investigaciones de Chris Stavroudis, la conductividad más adecuada para las superficies acrílicas es de $6000 \mu \mathrm{S}$ (Doherty 2012), aunque, en cualquier caso, siempre es recomendable hacer una medición previa de la superficie sobre la que se va a realizar la limpieza y ajustar la solución a los valores de la película pictórica.

\section{Métodos de limpieza gelificados y geles}

Los métodos de limpieza acuosos controlados mejoran el control de los tratamientos de limpieza. Sin embargo, la aplicación de las disoluciones de limpieza en "libre" mediante hisopos, ha demostrado seguir provocando la extracción de materiales solubles de la pintura y el hinchamiento de la misma. El primer acercamiento para reducir el exceso de humectación de la superficie durante la limpieza, lo propuso RichardWolbers en los años 80, mediante el uso de gelificantes poliméricos para espesar los disolventes, reteniendo así mejor los líquidos (Riedo 2017). La incorporación de sistemas gelificados o los denominados sistemas"gel-like"minimizaban los inconvenientes derivados de la aplicación de disolventes en libre. Por un lado, permitía la liberación controlada y lenta de la solución de limpieza, disminuyendo su penetración en la pintura y el riesgo de hinchamiento de la misma. Por otro lado, el aumento de la viscosidad reduciendo la difusión del material pictórico solubilizado en el sistema de limpieza. Así, se logra un tratamiento más selectivo, limitado a la zona sobre la que se aplica. La viscosidad también disminuye la evaporación del disolvente, mejorando el control de la acción de limpieza y reduciendo la toxicidad para los restauradores.

Entre los sistemas disponibles existen por un lado los llamados espesantes o gelificantes y por otro lado los geles. Los espesantes son sustancias que se añaden a una solución para aumentar su viscosidad (metil celulosa, carbopol, etc.). Los geles rígidos son materiales en forma de pasta rígida que mantienen el líquido en su estructura porosa interior (agar, goma-gellam, semi-interpenetrables). A caballo entre los espesantes y los geles, existen también los materiales "semi-blandos", las denominadas dispersiones poliméricas altamente viscosas (HVPD) (Angelova 2017).

La selección del método de aplicación depende de la naturaleza química del sistema de limpieza (disolvente, solución micelar, micro emulsión o disolución) que se trata de embeber o espesar. Para las disoluciones acuosas, existen varios métodos, tanto espesantes como geles measures ions' concentration in the solution and their mobility within it (Doherty 2012). The film formed by acrylic paint acts as a semipermeable membrane. The exchange of materials between the cleaning solution and the paint can occur through the surface micropores because of the osmotic force. This movement of materials occurs when the relative concentration of soluble salts of both parts tend to balance because they are different. Therefore, it is necessary to formulate isotonic cleaning solutions, that is, with ionic force values like those of paint, so that this ion exchange does not occur (Stavroudis 2013). According to the research of Chris Stavroudis, the most appropriate conductivity for acrylic surfaces is $6000 \mu \mathrm{S}$ (Doherty 2012). In all cases, it is recommended to measure the surface conductivity before starting the cleaning and adjust the solution to the values of the pictorial film.

\section{Gelifyed cleaning methods and gels}

Controlled aqueous cleaning methods improve the control of cleaning treatments. However, applying cleaning solutions in "free" employing swabs has been shown to continue causing both the extraction of soluble materials from the paint and the film's swelling. Richard Wolbers proposed the first approach to reduce excess wetting of the surface during cleaning in the 80 s by using polymeric gelling to thicken solvents, thus better-retaining liquids (Riedo 2017). Incorporating gelled systems or the so-called "gel-like" systems minimized the inconveniences arising from applying solvents in free. On the one hand, it allowed the controlled and slow release of the cleaning solution, reducing its penetration into the paint and the risk of swelling. On the other hand, the increase in viscosity reduces the diffusion of the solubilized pictorial material in the cleaning system. Thus, a more selective treatment is achieved, limited to the area on which it is applied. Viscosity also decreases solvent evaporation, improving the control of cleaning action and reducing toxicity to restorers.

Among the available systems, there are, on the one hand, the so-called thickeners or gelling agents and, on the other hand, the gels. Thickeners are substances added to a solution to increase its viscosity (methylcellulose, Carbopol, etc.). Rigid gels are rigid paste-shaped materials that keep the liquid in its inner porous structure (agar, gellam-gum, semi-interpenetrates). In the borderline between the thickeners and gels, there are also "semisoft"' materials, the so-called highly viscous polymeric dispersions (HVPD) (Angelova 2017).

The selection of the application method depends on the chemical nature of the cleaning system (solvent, micellar solution, microemulsion, or solution) that is to be embedded or thickened. For aqueous solutions, several methods can be used, including thickeners and rigid 


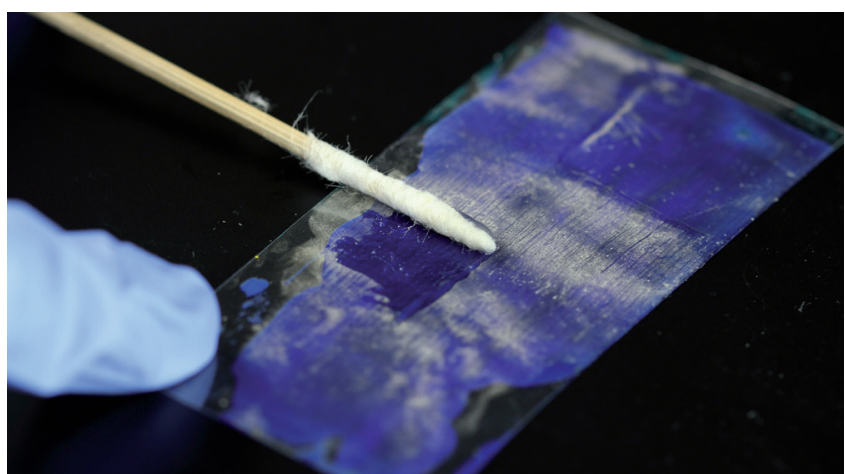

Figura/Figure 3- Aplicación de una disolución acuosa gelificada para la eliminación de suciedad superficial sobre un estrato de pintura acrílica. Fotografía de los autores en ensayos de laboratorio (2017). / Application of a gelified aqueous solution for the removal of surface dirt on a layer of acrylic paint. Photograph of authors in laboratory trials (2017).

rígidos que pueden ser empleados, aunque en el presente artículo nos centraremos en los geles rígidos como método de aplicación más inerte y eficaz (Baglioni 2014).

\section{Los geles rígidos}

En el sentido más amplio, un gel se define como un material que funciona como un sólido y que se puede deformar bajo una determinada tensión. Los geles tienen entre sus propiedades el punto de gelificación, conocido como "sol-gel". Este es el punto en el que el material pasa de comportarse como un líquido a algo similar a un sólido. El cambio se da por la formación de una agrupación infinita de redes que se expande por todo el sistema (Angelova 2017).

Existen principalmente dos tipos de geles: los físicos y los químicos. Los físicos se pasan de líquido a gel por un cambio de temperatura o modificación del pH. En este caso, el cambio es reversible y el gel puede volver a su líquido con el cambio de estas condiciones.

Sin embargo, en el caso de los geles químicos, la transición es irreversible, ocurre cuando la red se crea por uniones covalentes entre sus moléculas. Estos geles se usan como esponjas donde la red del gel se mantiene intacta mientras el líquido que soporta dentro se puede cambiar por otro (Angelova 2017).

Estas propiedades fisicoquímicas de los geles hacen que tengan numerosas aplicaciones. Por un lado, el gel puede ser aplicado en un área específica de la obra de arte sin expandirse. Por otro lado, el líquido dentro del gel se comporta como si estuviera libre entre la superficie de la obra y el gel, pudiendo solubilizar los productos necesarios (Angelova 2017).

\section{- Geles rígidos físicos}

En esta categoría se engloban los geles de agar-agar y las gomas.

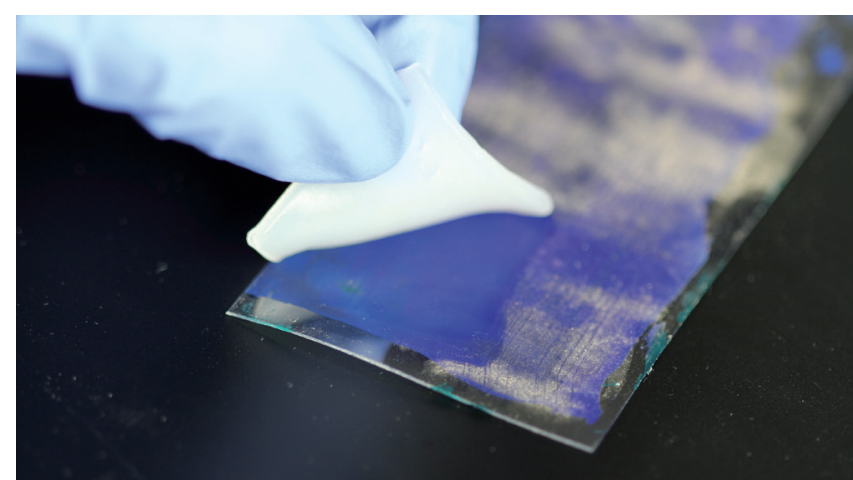

Figura/Figure 4- . Ejemplo de aplicación de un hidrogel cargado con una disolución tampón ajustada en pH y conductividad para la eliminación de suciedad superficial sobre un estrato de pintura acrílica. Fotografía de los autores en ensayos de laboratorio (2017). / Example of applying a hydrogel loaded with a buffer solution adjusted in $\mathrm{pH}$ and conductivity to remove surface dirt on a layer of acrylic paint. Photograph of authors in laboratory trials (2017).]

gels. However, this article will focus on rigid gels as the most inert and effective application method (Baglioni 2014).

\section{Rigid gels}

In the broadest sense, a gel is defined as a material that functions as a solid and deformed under specific stress. Gels have among their properties the gelling point, known as "sol-gel". This is when the material goes from behaving like a liquid to something like a solid. The change is due to the formation of an infinite grouping of networks that expands throughout the system (Angelova 2017).

There are mainly two types of gels: physical and chemical. Physic gels pass from liquid to gel by a change in temperature or $\mathrm{pH}$ modification. In this case, the change is reversible, and the gel can return to its liquid state when changing these conditions.

However, the transition is irreversible in chemical gels, occurring when covalent bonds between its molecules create the network. These gels are used as sponges where the gel network stays intact while the liquid that supports inside can be changed for another (Angelova 2017).

These physicochemical properties of gels make them have numerous applications. On the one hand, the gel can be applied to a specific artwork area without expanding. On the other hand, the liquid inside the gel behaves as if it were free between the surface of the work and the gel, solubilizing the necessary products (Angelova 2017).

\section{- Rigid physic gels}

This category includes agar-agar gels and gums. Both 
Ambas forman hidrogeles rígidos transparentes que cuando entran en contacto con la matriz porosa pueden retener grandes cantidades de agua. Los geles de agar son termorreversibles y se forman a partir de un proceso de calentamiento y enfriado (Bertasa 2017). Son fáciles de aplicar, aunque al tratarse de geles semi-rígidos preformados la adaptabilidad en superficies irregulares puede ser complicada. Además, la estructura interna de estos geles no tiene la capacidad suficiente para retener y liberar el líquido de manera controlada. Este inconveniente está siendo estudiado por algunos investigadores con el fin de mejorar la capacidad de control de los geles de agar (Sansonetti 2020; Diamond 2019; Cremonesi 2017), para lo que proponen crear geles con una concentración mayor de polímero.

\section{— Geles rígidos químicos}

Es el método de aplicación menos invasivo y con mayores ventajas empleado para la limpieza de superficies sensibles al agua. Se basa en la formación de una estructura formada por la polimerización de ciertos monómeros que da soporte al líquido. A diferencia de los gelesfísicos, la estructura interna y la porosidad de estos se puede modular, permitiendo un control mucho mayor de la liberación de la solución embebida. De esta manera, se logra una intervención más segura, fácil de aplicar y sin dejar residuos (Baglioni 2014).

El poly(vinyl alcohol) (PVA) es uno de los monómeros estudiados hasta el momento para la formación de estos geles. Se trata de un compuesto con gran capacidad de formar hidrogeles, fácil de adquirir, asequible y biodegradable. Uno de los geles propuestos a partir del PVA es el formado por PVA-borato. Se trata de un gel con interesantes características mecánicas, ya que se adaptan a las superficies perfectamente, son transparentes y fáciles de manipular. Ciertos estudios aseguran que se trata de un método libre de residuos (Angelova 2015), aunque otras investigaciones han demostrado que existen restos de borato tras aplicación en superficie.

Por otro lado, los criogeles de PVA obtenidos por ciclos de congelación y descongelación de la solución de polímero, son una herramienta muy válida para la eliminación de suciedad en superficies irregulares y sensibles (Khandekar 2000; Cárdaba 2020). Tienen una capacidad de adherencia bastante mayor que otros geles rígidos químicos, son blandos y bastante flexibles, lo que facilita el manejo de cara a las limpiezas.

Los geles de HEMA-VP son los más adecuados estudiados hasta el momento. Gracias a las características de estos monómeros, el gel se puede optimizar en función de las necesidades de retención, porosidad, comportamiento visco elástico e hidrofilicidad requerida (Cárdaba 2020). Son algo más rígidos que los criogeles de PVA por lo que se adaptan peor a las superficies irregulares. form transparent rigid hydrogels that can retain large amounts of water when in contact with the porous matrix. Agar gels are thermoreversible and are created from a heating and cooling process (Bertasa 2017). They are easy to apply, although being semi-rigid, gels adaptability on irregular surfaces can be complicated. In addition, the internal structure of these gels does not have sufficient capacity to retain and release the liquid in a controlled manner. Some researchers are studying this drawback to improve the controllability of agar gels (Sansonetti 2020; Diamond 2019; Cremonesi 2017). They propose creating gels with a higher concentration of polymer.

\section{— Rigid chemical gels}

It is the least invasive application method with the most outstanding advantages used for cleaning water-sensitive surfaces. It is based on forming a structure formed by the polymerization of specific monomers that supports the liquid. Unlike physical gels, the internal structure and porosity of these gels can be modulated, allowing much greater control of the release of the embedded solution. In this way, a safer intervention is achieved, easy to apply and without leaving residue (Baglioni 2014).

Poly (vinyl alcohol) (PVA) is one of the monomers studied so far to form these gels. It is a compound with a great capacity to form hydrogels, easy to acquire, affordable and biodegradable. One of the gels proposed from the PVA is the one developed by PVA-borate. It is a gel with interesting mechanical characteristics since it adapts to surfaces ideally, is transparent, and is easy to manipulate. Certain studies claim that it is a residuefree method (Angelova 2015), although other research has shown that there are traces of borate after surface application.

On the other hand, PVA cryogels obtained by freezing and thawing cycles of the polymer solution are a handy tool for removing dirt on irregular and sensitive surfaces (Khandekar 2000; Cardaba 2020). They have a much greater adhesion capacity than other chemical rigid gels; they are soft and quite flexible, facilitating handling in the face of cleanings.

HEMA-VP gels are the most suitable studied so far. Thanks to the characteristics of these monomers, gels can be optimized depending on the needs of retention, porosity, viscoelastic behaviour and required hydrophilicity (Cardaba 2020). They are somewhat stiffer than PVA cryogels, so they adapt worse to irregular surfaces.

\section{Conclusiones}

\section{Conclusions}

Las investigaciones sobre las limpiezas aplicadas a pinturas

Research on cleanings applied to contemporary 
contemporáneasestánencontinuodesarrollo.Laformulación de nuevos sistemas de limpieza se adapta según se avanza en el conocimiento de los materiales contemporáneos y se adoptan nuevos criterios de intervención.

Una de las conclusiones más reseñables es la necesidad de evaluar de forma individual las superficies a intervenir. El ajuste de los parámetros de $\mathrm{pH}$ y conductividad así como la consideración del residuo como uno de los inconvenientes más importantes a la hora de seleccionar el sistema más adecuado.

Aun considerando la viabilidad de otros métodos de limpieza de no-contacto como la nieve carbónica y el oxígeno atómico (Tsang 2011), este artículo se ha centrado en los métodos acuosos y geles por su mayor accesibilidad por parte la comunidad de restauradores. Los materiales empleados en los métodos descritos en el artículo están al alcance de la mayoría de los profesionales y el objetivo de este resumen es facilitar el conocimiento sobre ellos. Por otro lado, el trabajo pone especial énfasis en empleo de geles rígidos pro su versatilidad como herramienta más adecuada para el control de la liberación de las soluciones de limpieza y como método más seguro en términos de residuo. paintings is in continuous development. New cleaning systems are formulated as knowledge of contemporary materials advances and further intervention criteria are adopted.

One of the most meaningful conclusions is the need to evaluate the surfaces individually to be intervened. The adjustment of the $\mathrm{pH}$ and conductivity parameters and the consideration of the residue are among the essential drawbacks when selecting the most appropriate system.

Even considering the feasibility of other non-contact cleaning methods such as carbonic snow and atomic oxygen (Tsang, 2011), this article has focused on aqueous methods and gels for their greater accessibility by the community of restorers. The materials used in the practices described in the article are available to most professionals, and this summary aims to facilitate knowledge about them. On the other hand, the particular workplace emphasizes using rigid gels for their versatility as a more suitable tool for controlling the release of cleaning solutions and as a safer method in terms of residue.

\section{Referencias/References}

ANGELOVA, L; BERRIE, B.H.; GHETALDI, K.; KERR, A. ETWEISS, R.G. (2015).“Partially hydrolyzed poly(vinyl acetate)-borax-based gel-like materials for conservation of art: Characterization and applications" In Studies in Conservation, 60: 227-244 https://doi.org/10.1179/2047058413Y.0000000112

ANGELOVA, L.; CARRETI, E.; BERRIE, B.H.; WEISS, R.G. (2017). "Poly (vinyl alcohol)-borax "gels": a flexible cleaning option” In Gels in the Conservation of Art, Angelova L. (coord.). Londres: Archetype Publications Ltd, 231.

AGARWAL, N. \& FARRIS, R. J. (1999). «Water absorption by acrylic-based latex blend films and its effect on their properties», Journal of Applied Polymer Science, 72(11): 1407-1419.

ARAMENDIA, E. ET AL. (2003) «Distribution of surfactants near acrylic latex film surfaces: A comparison of conventional and reactive surfactants (surfmers)», Langmuir, 19(8): 3212-3221. https://doi.org/10.1021/la0267950

BAGLIONI, P.; BERTI, D.; BONINI, M.; CARRETI, E.; DEI, L.; FRATINI, E. ET GIGORGI, R. (2014)."Micelle, microemulsions and gels for the conservation of cultural heritage" In Advances in colloid and interface science, 205: 361-371 https://doi.org/10.1016/j.cis.2013.09.008

BELAROUI, F. ET AL. (2003). «Distribution of water-soluble and surface-active low-molecular-weight species in acrylic latex films», Journal of Colloid and Interface Science, 261(2): 336-348. https://doi.org/10.1016/S0021-9797(03)00098-5

BERTASA, M., CHIANTORE, O., POLI, T.; RIEDO, C.; DI TULLIO, V.; CANEVALI, C.; SANSONETTI, A. ET SCALARONE, D. (2017) “A study of commercial agar gels as cleaning materials" In Gels in the Conservation of Art, Angelova L. (coord.). Londres: Archetype Publications Ltd, 11

BURNSTOCK, A. \& VAN DEN BERG, K. J. (2005) «A pilot study of the effects of triammonium citrate solutions used for surface cleaning paintings», Postprints (American Institute for Conservation of Historic and Artistic Works. Paintings Specialty Group), 17: 56-64.

BUTLER, L. N., FELLOWS, C. M. Y GILBERT, R. G. (2003) «Water sensitivity of latex-based films», Industrial and Engineering Chemistry Research, 42(3): 456-464. https://doi.org/10.1021/ie020611v

CARDABA, I.; POGGI, G.; BAGLIONI, M.; CHELAZZI, D.; MAGUREGUI, I. ET GIORGI, R. (2020). “Assessment of aqueous cleaning of acrylic paints using innovative cryogels", Microchemical Journal, 152: 104311. https://doi.org/10.1016/j.microc.2019.104311

CREMONESI, P. ET CASOLI, A. (2017). "Thermo-reversible rigid agar hydrogels: their properties and action in cleaning” In Gels in the Conservation of Art, Angelova L. (coord.). Londres: Archetype Publications Ltd, 19 
CROLL, S. (2007). «Overview of developments in the paint industry since 1930», In Learner, T. J. S. et al. (eds.) Modern paints uncovered:proceedings from the modern paints uncovered symposium. Getty Conservation Institute (Getty Conservation Institute symposium proceedings series), 17-29.

DIGNEY-PEER, S. ET AL. (2004). «The migration of surfactants in acrylic emulsion paint films», In Modern art, new museums: contributions to the Bilbao Congress, 13-17 September 2004, 202-207.

DILLON, C. E., LAGALANTE, A. F. Y WOLBERS, R. C. (2014) «Acrylic emulsion paint films: The effect of solution pH, conductivity, and ionic strength on film swelling and surfactant removal», Studies in Conservation, 59(1): 59-62. https://doi.org/10.1179/2047058412Y.0000000076

DIMOND, O.; BARKOVIC, M.; CROSS, M. ET ORMSBY, B. (2019). “The role of agar gel in treating water stains on acrylic paintings: Case study of Composition, 1963 by Justin Knowles" In Journal of the American Institute for Conservation, 58: 144-157. https://doi.org/ $\underline{10.1080 / 01971360.2019 .1570431}$

DOHERTY, T. ET STAVROUDIS, C. (2012). "Desarrollando sistemas de limpieza para pinturas sensibles al agua mediante ajuste del pH y de la conductividad". In Conservación de arte contemporáneo: 13a jornadas, febrero 2012, Centro de Arte Reina Sofía, Departamento de ConservaciónRestauración, 39-48.

DOMÉNECH-CARBÓ, M. T. ET AL. (2013) «Multitechnique Approach to Evaluate Cleaning Treatments for Acrylic and Polyvinyl Acetate Paints», In New Insights into the Cleaning of Paintings: Proceedings from the Cleaning 2010 International Conference, Universidad Politecnica de Valencia and Museum Conservation Institute, 125-134.

FELLER, R. L. ET AL. (1993). Artists' pigments: a handbook of their history and characteristics, volume 2. Editado por A. Roy. National Gallery of Art.

HAGAN, E. ET AL. (2007). «Factors affecting the mechanical properties of modern paints», In Modern paints uncovered: proceedings from the modern paints uncovered symposium, 227-235.

HAGAN, E. W. S. ET AL. (2011). «Influence of the inorganic phase concentration and geometry on the viscoelastic properties of latex coatings through the glass-transition», Polymer, 52(7): 1662-1673. https://doi.org/10.1016/j.polymer.2011.01.060

HAGAN, E. W. S. ET AL. (2015). «The effects of strain rate and temperature on commercial acrylic artist paints aged one year to decades», Applied Physics A, 121(3): 823-835. https://doi.org/10.1007/s00339-015-9423-6

HAYES, J., GOLDEN, M. \& SMITH, G. D. (2007). «From formulation to finished product: causes and potential cures for conservation concerns in acrylic emulsion paints», In Modern paints uncovered: proceedings from the modern paints uncovered symposium, 58-65.

HOGFELDT, E. ET AL. (1989). «Application of a simple three-parameter model to titration data for some linear polyelectrolytes», Acta Chem. Scand, 43(5): 496-499. https://doi.org/10.3891/acta.chem.scand.43-0496

HOOGLAND, F. G. Y BOON, J. J. (2009). «Analytical mass spectrometry of poly(ethylene glycol) additives in artists' acrylic emulsion media, artists' paints, and microsamples from acrylic paintings using MALDI-MS and nanospray-ESI-MS», International Journal of Mass Spectrometry, 284(1-3): 72-80. https://doi.org/10.1016/j.jjms.2009.03.002

JABLONSKI, E. ET AL. (2003). «Conservation concerns for acrylic emulsion paints», Reviews in conservation, 4: 3-12. https://doi.org/10.1179/ sic.2003.48.Supplement-1.3

KAMPASAKALI, E. ET AL. (2011). «A preliminary study into the swelling behavior of artists' acrylic emulsion paint films», In ICOM-CC 16th triennial conference Lisbon 19-23 September 2011: preprints.

KHANDEKAR, N (2000). "A survey of the conservation literature relating to the development of aqueous gel cleaning on painted and varnished surfaces" In Reviews in conservation, IIC, London, 1: 10-20 https://doi.org/10.1179/sic.2000.45.s3.003

LEARNER, T. (2004). Analysis of modern paints. Getty Publications.

LEÓN, T. L. (2006). Efectos Hofmeister en partículas coloidales. Editorial de la Universidad de Granada.

MALLÉGOL, J. ET AL. (2002). «Origins and effects of a surfactant excess near the surface of waterborne acrylic pressure-sensitive adhesives», Langmuir, 18(11): 4478-4487. https://doi.org/10.1021/la0117698

MECKLENBURG, M. F. \& TUMOSA, C. S. (1991). «An Introduction into the Mechanical Behavior of Paintings under Rapid Loading Conditions», In 
Art in Transit: Studies in the Transport of Paintings, 137-171.

MORRISON, R. ET AL. (2007) «An Investigation of Parameters for the Use of Citrate Solutions for Surface Cleaning Unvarnished Paintings», Studies in Conservation, 52(4): 255-270. https://doi.org/10.2307/20619514

MURRAY, A. ET AL. (2002) «The condition and cleaning of acrylic emulsion paintings», In Materials issues in art and archaeology VI: symposium held November 26-30, 2001, Boston, Massachusetts, USA, 83-90.

ORMSBY, B. A. ET AL. (2009) «An FTIR-based exploration of the effects of wet cleaning treatments on artists' acrylic emulsion paint films», e Preservation Science, 6: 186-195. http://aata.getty.edu/Record

ORMSBY, B.; LEARNER, T.; SCHILLING, M.; DRUZIK, J.; KHANJIAN, H. ET FOSTER, G. (2006). “The effects of surface cleaning on acrylic emulsion paintings: a preliminary investigation" In Tate Papers [Tate's Online Research Journal] 6: 1-14. https://www.tate.org.uk/research/publications/ tate-papers/06/effects-of-surface-cleaning-on-acrylic-emulsion-painting-preliminary-investigation

ORMSBY, B. A ET AL. (2007) «Wet cleaning acrylic emulsion paint films: an evaluation of physical, chemical, and optical changes», Modern paints uncovered: proceedings from the modern paints uncovered symposium, 189-200.

ORMSBY, B. \& LEARNER, T. (2009) «The effects of wet surface cleaning treatments on acrylic emulsion artists' paints: a review of recent scientific research», Reviews in conservation, 10(10): 29-41. https://doi.org/10.1179/sic.2010.55.Supplement-1.29

ORMSBY, B.; SOLDANO, A.; KEEFE, M. H.; PHENIX, A. ET LEARNER, T. (2010). “An Empirical Evaluation of a Range of Cleaning Agents for Removing Dirt from Artists' Acrylic emulsion Paints"In AIC Paintings Specialty Group Postprints, 23: 77-87.

ORMSBY, B. \& LEARNER, T. (2014). «Artists' acrylic emulsion paints: materials, meaning and conservation treatment options», AICCM bulletin, 34: 57-65. https://doi.org/10.1179/bac.2013.34.1.007

ORMSBY, B.; LEARNER, T.; FOSTER, G.; DRUZIK, J. ET SCHILLING, M. (2007). “Wet-cleaning acrylic emulsion paint films: an evaluation of physical, chemical, and optical changes" In Modern Paints Uncovered: Proceedings from the Modern Paints Uncovered Symposium, T.J.S. Learner,P. Smithen, J.W. Krueger, M.R. Schilling (Eds.), Getty Conservation Institute, Los Angeles, California,189-200.

OWEN, L., PLOEGER, R. \& MURRAY, A. (2004). «The effects of water exposure on surface characteristics of acrylic emulsion paints», Journal of the Canadian Association for Conservation = Journal de l'Association canadienne pour la conservation et la restauration, 29(613): 8-25.

PLOEGER, R. ET AL. (2005). «An investigation of the chemical changes of artists' acrylic paint films when exposed to water», In Materials issues in art and archaeology VII: symposium held November 30-December 3, 2004, Boston, Massachusetts, U.S.A., 49-56. https://doi.org/10.1557/PROC-852-003.4.

PLOEGER, R. ET AL. (2007). «Morphological changes and rates of leaching of water-soluble material from artists' acrylic paint films during aqueous immersions», Modern paints uncovered: proceedings from the modern paints uncovered symposium, 201-207.

PLOEGER, R. E. ET AL. (2004). «Infrared analysis of materials leached by water from acrylic paint films», Proceedings of the Sixth Infrared and Raman Users Group (IRUG), 46-51.

RIEDO, C.; ROLLO, G.; SCALARONE, D. ET CHIANTORE, O. (2017). "Improved PVA gels for the cleaning of painted surfaces". In Gels in the Conservation of Art, Angelova L. (coord.). Londres: Archetype Publications Ltd, 283

SAULNIER, G. ET TTHIBAULT, M.E. (2005).“Cleaning Acrylic Emulsion Paints: A two-part study”In AIC PSG Postprints, Portland, Oregon, 17: 1- 8

SANSONETTI, A.; BERTASA, M.; CANEVALI, C.; RABBOLINI, A.; ANZANI, M. ET SCALARONE, D. (2020). "A review in using agar gels for cleaning art surfaces" In Journal of Cultural Heritage, 44: 285-296 https://doi.org/10.1016/j.culher.2020.01.008

SCALARONE, D. \& CHIANTORE, O. (2004). «Separation techniques for the analysis of artists' acrylic emulsion paints», Journal of Separation Science, 27(4): 263-274. https://doi.org/10.1002/jssc.200301638

SMITH, G. D. (2007) «Aging characteristics of a contemporary acrylic emulsion used in artists' paints», en Modern paints uncovered: proceedings from the modern paints uncovered symposium, 236-246.

SMITHEN, P. (2007). «A history of the treatment of acrylic painting», In Modern paints uncovered: proceedings from the modern paints uncovered symposium, 165-174. 
SNUPAREK, J. ET AL. (1983). «Water Absorption in Acrylic Latex Films.», Journal of Applied Polymer Science, 28(4): 1421-1428.

DE SOUSA RAMOS FÉLIX SILVA, M. (2011). Analytical study of accelerated light ageing and cleaning effects on acrylic and PVAc dispersion paints used in Modern and Contemporary Art. Universitat Politècnica de València.

SOLBES-GARCIA, A.; MIRANDA-VIDALES, J.M.; NIETO-VILLENA, A.; HERNANDEZ, L.S. ET NARVÁEZ, L. (2017). "Evaluation of the oxalic and tartaric acids as an alternative to citric acid in aqueous cleaning systems for the conservation of contemporary acrylic paintings", en Journal of Cultural Heritage, 25: 127-134. https://doi.org/10.1016/j.culher.2016.11.013

STAVROUDIS, C. Y DOHERTY, T. (2013). "The Modular Cleaning Program in Practice: Application to Acrylic Paintings", en New Insights into the Cleaning of Paintings: Proceedings from the Cleaning 2010 International Conference, Universidad Politecnica de Valencia and Museum Conservation Institute, 139-145.

TSANG, J.S. Y BABO, S. (2011). Soot removal from acrylic emulsion paint test panels: a study of dry and non-contact cleaning, en ICOM Committee for Conservation 16th Triennial Meeting Lisbon Portugal 19-23 September 2011

WHITMORE, P. M. Y COLALUCA, V. G. (1995). «The natural and accelerated aging of an acrylic artists' medium.», Studies in conservation, 40(1): $51-64$. https://doi.org/10.1179/sic.1995.40.1.51

WHITMORE, P. M., COLALUCA, V. G. Y FARRELL, E. (1996). «A note on the origin of turbidity in films of an artist's acrylic paint medium», Studies in conservation, 41(4): 250-255. https://doi.org/10.1179/sic.1996.41.4.250

WHITMORE, P. M., MORRIS, H. R. Y COLALUCA, V. G. (2007). «Penetration of liquid water through waterborne acrylic coatings», en Learner, T. J. S. et al. (eds.) Modern paints uncovered: proceedings from the modern paints uncovered symposium. Getty Conservation Institute (Getty Conservation Institute symposium proceedings series), 217-223.

WICKS, Z. W. ET AL. (2007). Organic coatings: science and technology, Third edition, John Wiley \& Sons, Inc. Disponible en: http://pubs.acs.org/cgiin/doilookup/?10.1021/ie50472a014.

WOLBERS, R. C., NORBUTUS, A. Y LAGALANTE, A. (2012). «Cleaning of Acrylic Emulsion Paints: Preliminary Extractive Studies with Two Commercial Paint Systems», Smithsonian Contributions to Museum Conservation 2, 3(November 2010), 148-157.

ZHANG, Y. Y CREMER, P. S. (2006). «Interactions between macromolecules and ions: the Hofmeister series», Current Opinion in Chemical Biology, 10(6): 658-663. https://doi.org/10.1016/j.cbpa.2006.09.020

ZIRALDO, I., KRISTEN WATTS, ARNOLD LUK, ANTHONY F. LAGALANTE \& RICHARD C. WOLBERS (2016) The influence of temperature and humidity on swelling and surfactant migration in acrylic emulsion paint films, Studies in Conservation, 61(4): 209-221 https://doi.org/10.1179/204705841 4Y.0000000156

ZUMBÜHL, S. ET AL. (2007). «Solvent action on dispersion paint systems and the influence on the morphology: changes and destruction of the latex microstructure», en Learner, T. J. S. et al. (eds.) Modern paints uncovered: proceedings from the modern paints uncovered symposium. Getty Conservation Institute (Getty Conservation Institute symposium proceedings series), 257-268.

\section{Autor/es}

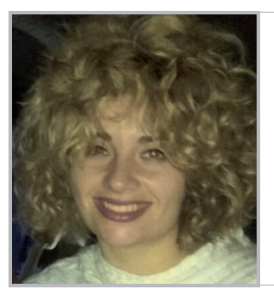

\section{Irene Cárdaba López}

icardaba@gipuzkoa.eus

Gordailua, Centro de Colecciones Patrimoniales de Gipuzkoa

https://orcid.org/0000-0002-4041-2689

Graduada en Conservación y Restauración de Bienes Culturales en la Universidad del País Vasco/Euskal Herriko Unibertsitatea, con Premio Extraordinario Fin de Carrera y Máster en Rehabilitación, Restauración y Gestión Integral de Patrimonio Construido en la misma universidad. Actualmente, Técnico Conservadora Restauradora en Gordailua, Centro de Colecciones Patrimoniales de Gipuzkoa. Trabajando principalmente en la conservación 
preventiva de las colecciones así como en la dirección de proyectos de restauración en el centro Gordailua y del patrimonio mueble del territorio de Gipuzkoa. Simultáneamente en fase de concluir el doctorado sobre "Limpiezas aplicadas a pinturas de emulsión acrílica", dentro del programa de doctorado de Estrategias Científicas Interdisplinares en Patrimonio y Paisaje de la Universidad del País Vasco/ Euskal Herriko Unibertsitatea.

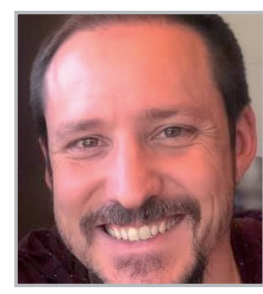

\section{Álvaro Solbes García}

alvaro.solbes@uaslp.mx

Universidad Autónoma de San Luis Potosí (México)

https://orcid.org/0000-0003-4045-0930

Licenciado en Historia del Arte por la Universidad de Valencia y Máster en Conservación y Restauración de Bienes Culturales por la Universidad Politécnica de Valencia. Doctor en Ingeniería y Ciencia de Materiales por la Universidad Autónoma de San Luis Potosí. Restaurador para instituciones de la conservación del Patrimonio como el Instituto Valenciano de Conservación y Restauración o Fundación 'La Luz de las Imágenes', actualmente es profesorinvestigador en la Licenciatura de Conservación y Restauración de Bienes Culturales Muebles de la UASLP. Realiza proyectos de investigación para la conservación de Arte Contemporáneo y métodos de limpieza en pinturas acrílicas. Premio nacional Paul Coremans en el área de Conservación del Instituto Nacional de Antropología e Historia (México), pertenece desde 2019 al Sistema Nacional de Investigadores del CONACYT.

Artículo enviado el 08/11/2021 Artículo aceptado el 28/11/2021

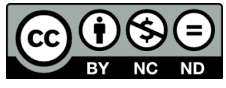

https://doi.org/10.37558/gec.v20i.1075 